\title{
An Assessment of Onion Post Harvest Loss in Desert Prone Front Line Area of Kano State Nigeria
}

\author{
Salisu Lawal Halliru Aliyu Shu'aibu Muhammad Zahara'u Ishaq Umar \\ Department of Geography, School of Secondary Education (Arts and Social Sciences) \\ Federal College of Education, Kano
}

\begin{abstract}
Most of the farmers in Kura local government area bring onions directly to the market after harvest as proper storage facilities are not available with them. It is against this, farmers usually unload their entire stock within a month of harvest, during which prices are very low thereby making them to be at the last receiving end. The objective of this research is to identify the causes of onions post-harvest losses, indigenous technologies used for Onion storage and to design and develop natural ventilated Onion storage structured model using local resources. Mixed methods were employed through the use of a structured questionnaire encompassing both open and closeended questions as well interview. The population of the study consist of the Onion farmers in the three (3) major onion production communities at which 254 farmers were selected. The study reveals that the most constraining factor with almost $75 \%$ is inadequate storage facilities. It also disclosed that the present storage structure is hanging method, spreading on the floor mud and traditional silos (Rumbu). It was concluded that natural ventilated onion storage structure (Makani model) should be developed in order to provide good ventilated condition which will reduce the rotting losses. Therefore, the study recommends that government and private organization should assist the cultivars with modern onion storage facilities to avoid further post-harvest loss.
\end{abstract}

Keywords: Onions; Kura; production; post harvest loss

DOI: $10.7176 / \mathrm{JBAH} / 9-4-07$

\subsection{Introduction}

Onions (Allium cepa L.) are bulbous vegetables from the Liliaceae family. Onions are important vegetable crops grown mainly as food materials for domestic consumption and export in most part of the world particularly the varieties that are grown for bulbs. The global onion production figures have shown an upward trend of $51.6 \%$ with a production volume of 33 million tons in 2003 and 64 million tons in 2007 (Food and Agriculture Organization of the United Nations (FAO, 2010) and 74,250,809 tonnes from an area of 4,364,000 hectares (FAO, 2012) with Nigeria having up to 618,000 tons in the year 2007 (FAO, 2010). In terms of global weight of vegetables produced only tomatoes and cabbages exceed bulb onions in importance. Allium (Onion) is highly valued for their flavor, nutritional value and herbs because of their richness in vitamins (such as vitamins A and C), protein, minerals, and fiber. Allium (Onion) have interesting technological properties and beneficial health effects such as antioxidant, anticarcinogenic, antimicrobial, prebiotic, hypolipidemic, and antithrombotic properties that made them to have been revered not only for their culinary use, but also for their therapeutic properties (María, 2009) since 6th century as a medicine. No wonder, because of these properties, Onion is grown in at least 175 countries (FAO) with China and India as the primary onion growing countries, followed by the USA, Egypt, Iran, Turkey, Pakistan, Brazil, the Russian Federation, and the Republic of Korea (FAO, 2012). Thus, the importance of Onions made it popular among poor people throughout the world including Nigeria for meals and herbal remedy of colds, coughs, bronchitis, anemia, cholera, influenza, disorders of urinary system and bleeding piles. However, the crop is one of the most important sources of income for smallholder farmers, women, young people and all actors engaged in the production-consumption chain.

Although onion is considered as a semi perishable crop, yet it is a delicate product to store due to its high water content. Depending on cultivar type and pre harvest as well as post harvest treatments, onion bulbs can be stored at low temperature as $0-5^{\circ} \mathrm{C}$ or high temperature $\left(25-30^{\circ} \mathrm{C}\right)$ maintaining the relative humidity in the range of 55\%-70\% (Chope, 2006 and Kukanoor, 2005). The overall storage losses under these storage conditions are high and generally increase with the increase in storage period. Hence, like every agricultural commodity, Onion requires to be stored properly to prevent it from qualitative and quantitative losses because of its process of development towards sprouting and decay by various disease causing organisms.

Onion (Allium cepal L.) is one of the major commercial vegetable crops grown in most parts of Nigeria in various states such as Borno, Sokoto, Kebbi, Jigawa, Zamfara, Kaduna and Kano because of its market profitable (Agricultural Extension Research and Liaison Services, 1985) with estimated revenue of N 206.7 per bag in 2004 (Abduljabar, 2004).

Kura Local Government area in one of such areas of Kano State where Onion in grown in large quantity mostly during the dry season with inadequate storage capacities that are mostly traditional and unscientific. As a result, during this period prices rule very low due to glut situation. Thereafter, the rise in prices is quite rapid and sometimes wide fluctuations occur leading to dissatisfaction amongst the producers as well as consumers. During 
this bulk production period, onion growers either sell their produce at low price in fear of high storage loss or store for a few days using traditional methods under ambient environment. In both cases, dealers have more control of onion price in favor of the growers because of poor or unavailability of storage facilities such as cold storage and where they are available they are beyond the reach of small holder farmers. These necessitate most of the farmers in Kura local government area to bring their onion directly to the market after harvest in order to avoid post-harvest loss. As posited by Mrema and Rolle, (2002) that about 20-40\% of Onion are losses after Post-harvest due to inefficient storage techniques. This research intends to identify the causes of onions post-harvest losses incurred by the farmers and indigenous technologies used for Onion storage with the view to find the lasting solution of the post harvest loss incurred by the onion farmers.

\subsection{Materials and Methods}

Kura is an agrarian Local Government Area in the southern part of Kano State and its economy is mainly based on agricultural production. The area has a population of 144,601 people (NPC, 2006) with a land mass of $206 \mathrm{sq}$ $\mathrm{km}$, located between $11^{\circ} 46^{\mathrm{I}} 12.84^{\mathrm{II}} \mathrm{N}$ and longitude $8^{\circ} 35^{\mathrm{I}} 29.02^{\mathrm{II}} \mathrm{E}$. It is about 900kilometer from the edge of the Sahara desert and 1,140 kilometer away from the Atlantic Ocean approximately. It shares boundaries with Kumbotso in the north and east and from west to south it boarders with Madobi and Garun Malan local government area respectively and in the extreme south - east it boarders with Bunkure local government area.(fig.1).

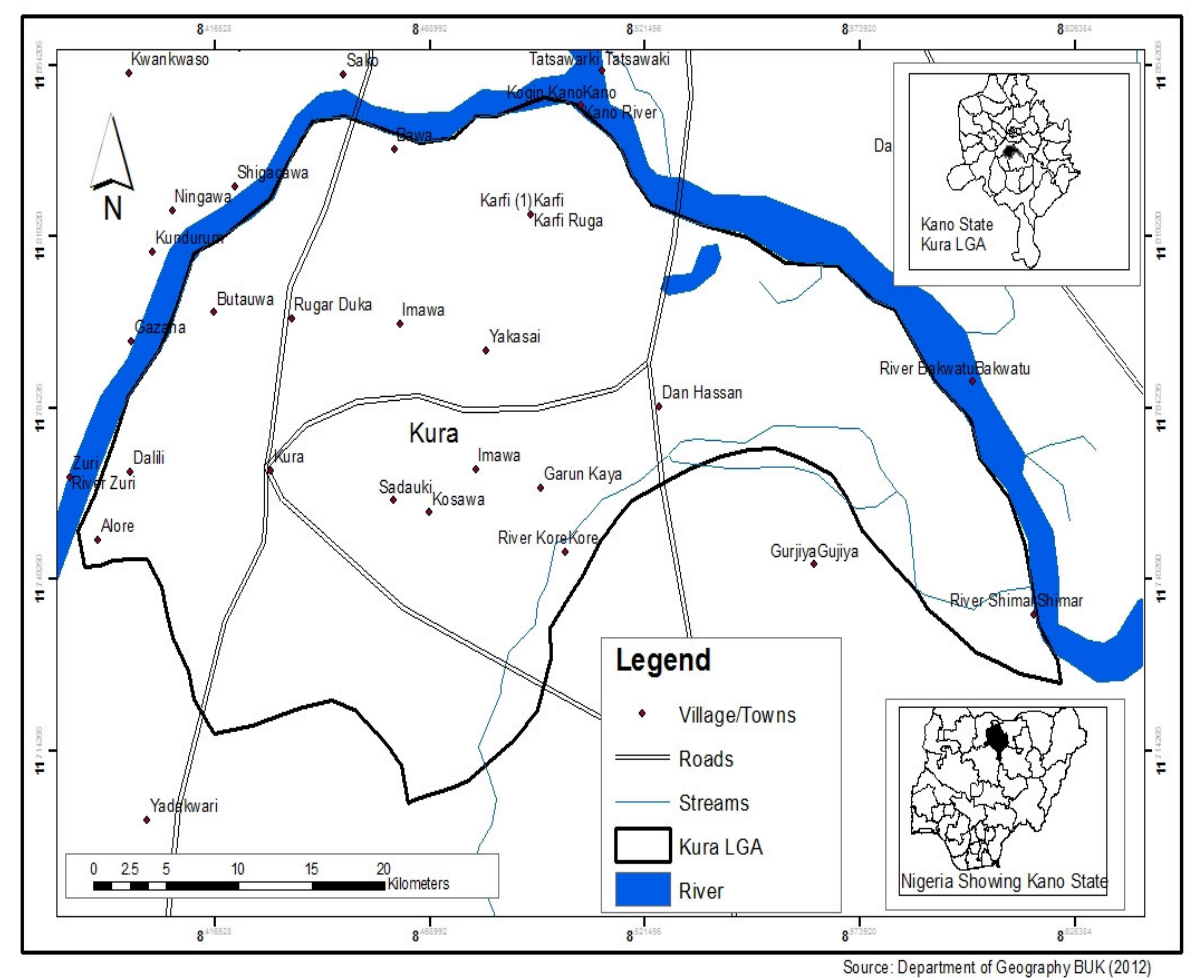

Fig 1: Map of Kano state showing the study area Kura local Government

The area has four marked temperature regimes; Dry and Cool season (kaka), Dry and Hot season (bazara), Wet and Warm season (damina) Dry and warm season (rani) with mean annual temperature of $26^{\circ} \mathrm{c}$ and $21^{\circ} \mathrm{c}$ main monthly range of maximum temperature in December/January and over $35^{\circ} \mathrm{c}$ which is hottest (April/May) wet season start in May and ends October (Olofin, 2008). While November to February is dry cool season with hamattan haze. Vegetation is savanna (grassland) of Sahel Sudan guinea type. Majority of people in the study area are farmers who traditionally acquired their farm land by inheritance and they adopted irrigated farming as a viable option to rain-fed agriculture. The predominant Muslim Hausa and Fulani of the study area have their local industries and occupations as: blacksmithing, brick moulding, dyeing, hunting, fishing and trading.

This study is based on a mixed method approach that include, qualitative and quantitative research techniques; the methods were employed through the use of a structured questionnaire encompassing both open-ended and close-ended question. The population of the study consist of the Onion farmers in the three (3) major communities that excel in Onion production in the study area, namely: Gundutse, Karfi and Dan Hassan wards (plate 1). The traget population identified for the study were 660 farmers with Gundutse, Karfi and Dan Hassan having 420, 120 and 120 farmers respectively. The required sample size of the study based on Krejcie and Morgan (1970) table of 
sample size is 242 . Five (5) percent attrition rate was added to avoid mortality, totaling to 254 and shared proportionately among the population. Based on this Gundutse has 162, Karfi and Dan Hassan have 46 respondents respectively. The data collected for the study were conducted from July $20^{\text {th }}$ to $26^{\text {th }}$ August, 2018 using questionnaires techniques in order to facilitate a better understanding of the data generated in the research process with the help research assistants.

The data obtained from the questionnaires were analyzed using descriptive statistics with the help of Microsoft Excel.

\section{3: Results and Discussions}

\subsection{Causes of Post harvest loss}

Data obtained on the causes of Post harvest loss in the area indicated that, all the onion farmers' experiences post harvest loss, table 1.

Table 1: Experiences Onion post-harvest losses

\begin{tabular}{|l|r|r|r|r|r|r|r|r|}
\hline & \multicolumn{1}{|c|}{ Gundutse } & \multicolumn{1}{c|}{$\%$} & \multicolumn{1}{|c|}{ Danhassan } & \multicolumn{1}{c|}{ To } & \multicolumn{1}{c|}{ Karfi } & \multicolumn{1}{c|}{$\%$} & \multicolumn{1}{c|}{ Total } & $\%$ \\
\hline Yes & 153 & 100 & 47 & 100 & 46 & 100 & 246 & 100 \\
\hline No & 0 & 00.00 & 0 & 00.00 & 0 & 00.00 & 0 & 00.00 \\
\hline Total & 153 & & 47 & & 46 & & 246 & 100 \\
\hline
\end{tabular}

Data Analysis 2018

This post harvest loss is caused by Animals (rodents, rat and insect) (23.98\%), Inadequate storage facilities $(75.20 \%)$ and insignificant contribution of inappropriate transportation facilities $(0.81 \%)$ as shown in figure 2.

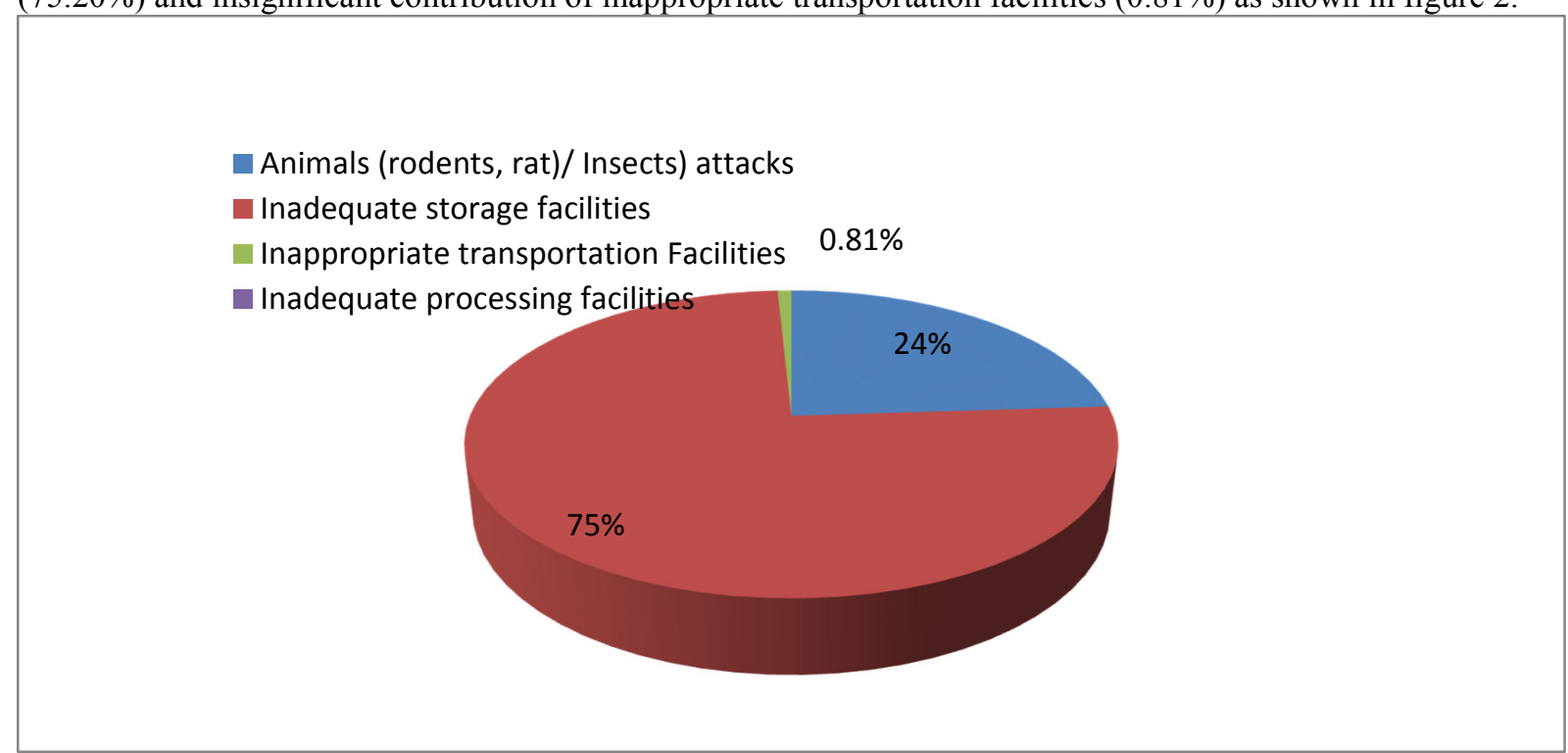

Figure 2: Factors responsible for Post harvest loss

Inadequate storage facilities were recorded to be the highest causes of post harvest loss in the area. This incidence makes the farmers to incur loss in economic terms. Some of the respondents revealed that, out of hundred (100) bags of onion stored after harvesting is hardly to get thirty (30) bags in a year. This necessitate some farmers to sell their products immediately after harvesting at farm point or to market directly (plate 1 and 2) 

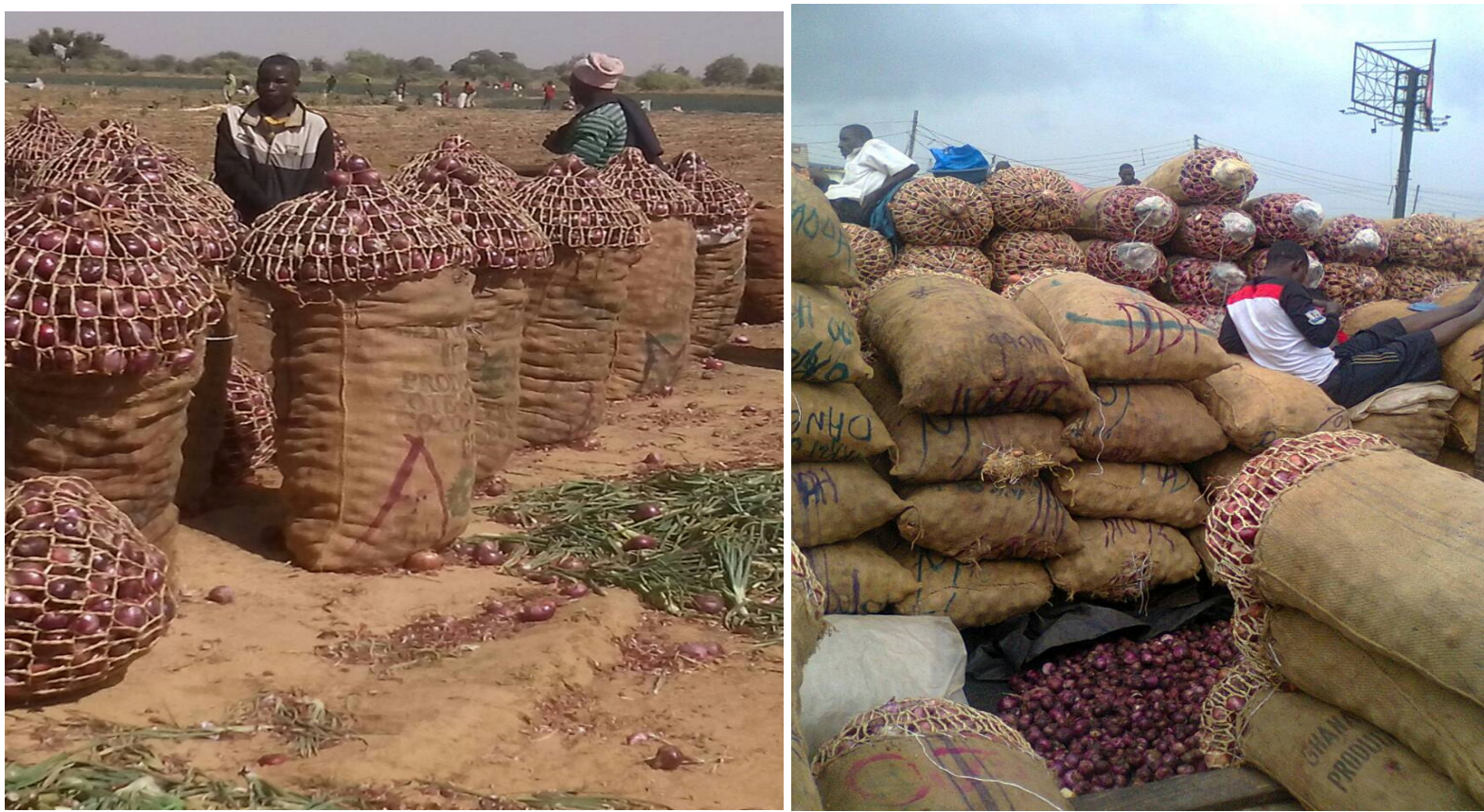

Plate 1: Onion farmland

Plate 2: Onion Market at Gundutse

\subsection{Indigenous Methods of Onion storage facility}

The high rate of post harvest loss in the study area necessitate the farmers to adopt various methods of storing the onion such as local store (Rumbu), top of the roofing, use of basket, hanging method, spreading on the floor and spreading under tree in order to avoid post harvest losses and each method use depends on the ability and capability of the individual farmer. As indicated in table 2 majority of the respondents (39.02) in the area use top of their roofing as a means of storing their products (Onion) and the use of basket (28.46) as shown in plate 3

Table 2: Indigenous (Local) Method Used For Onion Storage

\begin{tabular}{|l|l|l|l|l|l|l|r|r|}
\hline & Gundutse & $\mathbf{\%}$ & Danhassan & $\mathbf{\%}$ & Karfi & \% & Total & \\
\hline Local store (Rumbu) & 02 & 1.31 & 1 & 2.13 & 1 & 2.17 & 4 & 1.63 \\
\hline At the top of a roofing & 53 & 34.64 & 24 & 51.06 & 19 & 41.3 & 96 & 39.02 \\
\hline In a basket (Kwando) & 42 & 27.45 & 12 & 25.53 & 16 & 34.78 & 70 & 28.46 \\
\hline Hanging method & 20 & 13.07 & 6 & 12.77 & 4 & 8.70 & 30 & 12.2 \\
\hline Spreading on the floor (mud) & 31 & 20.26 & 3 & 6.38 & 6 & 13.04 & 40 & 16.26 \\
\hline Spreading under tree & 5 & 3.27 & 1 & 2.13 & 0 & 00.00 & 06 & 2.44 \\
\hline Total & 153 & 100 & 47 & 100 & 46 & 100 & 246 & 100 \\
\hline
\end{tabular}

Source: Data Analysis 2018 


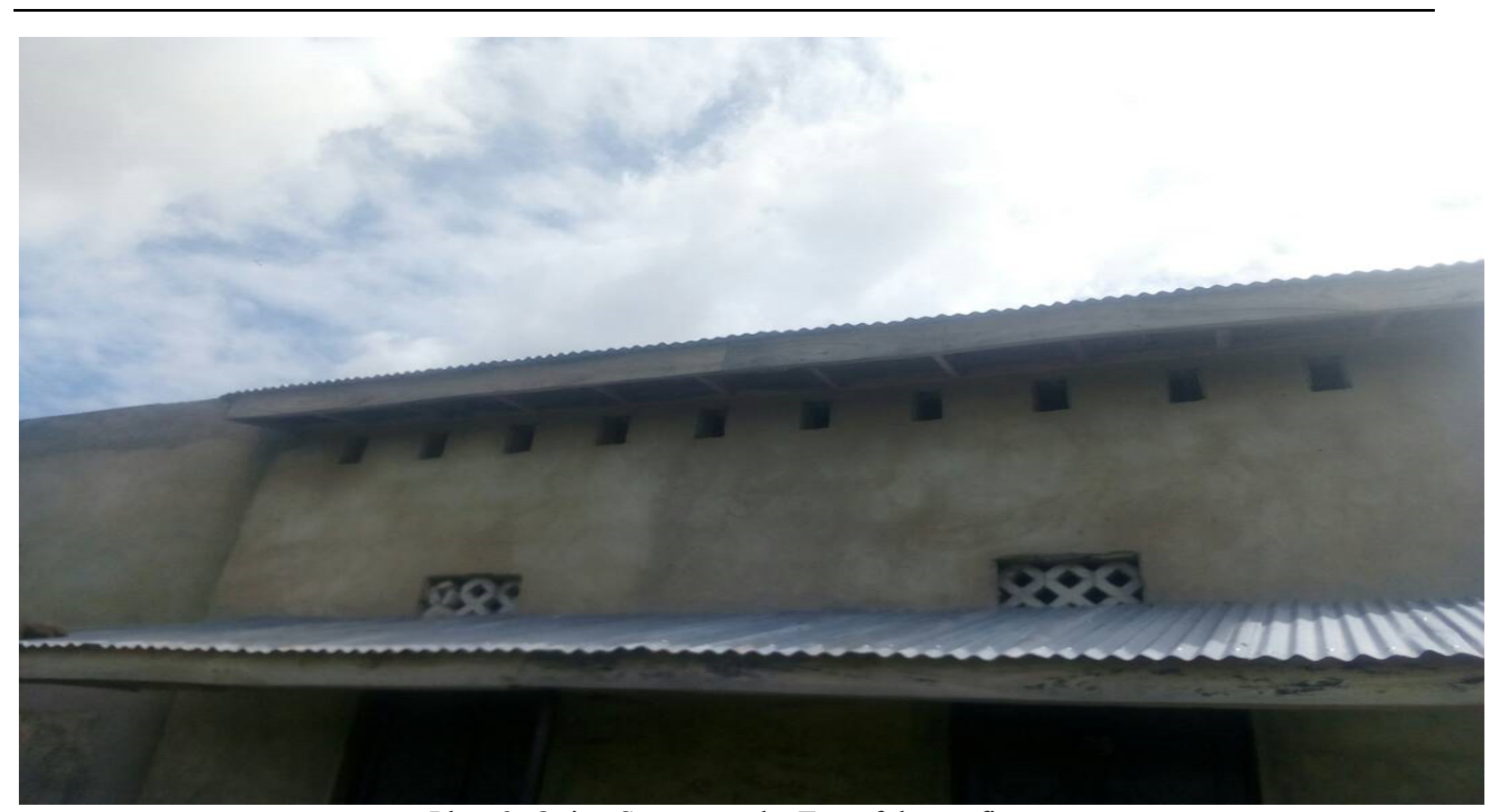

Plate 3: Onion Storage at the Top of the roofing

The rate of Onion loss incurs at storage duration post harvest as indicated by farmers/cultivars is between $31 \%$ and above of the total Onion produce by farmers $(87.4 \%)$ in all the sampled areas of the study area with the exception of very few farmers (4.47\%) that experiences about $11-20 \%$ loss of the Onion (table 3 ) as a results of unscientific method of storage facilities like top of the roofing and baskets.

Table 3: Rate of Onion loss incur at Storage

\begin{tabular}{|l|r|r|r|r|r|r|r|r|}
\hline Rate & \multicolumn{1}{|c|}{ Gundutse } & \multicolumn{1}{c|}{ \% } & \multicolumn{1}{c|}{ Danhassan } & \multicolumn{1}{c|}{ \% } & \multicolumn{1}{c|}{ Karfi } & \multicolumn{1}{c|}{ Total } & \multicolumn{1}{l|}{$\%$} \\
\hline $1-5 \%$, & 0 & 00.00 & 0 & 00.00 & 0 & 00.00 & 0 & 00.00 \\
\hline $6-10 \%$, & 0 & 00.00 & 0 & 00.00 & 0 & 00.00 & 0 & 00.00 \\
\hline $11-20 \%$, & 6 & 3.92 & 1 & 2.13 & 4 & 8.7 & 11 & 4.47 \\
\hline $21-30 \%$, & 10 & 6.54 & 4 & 8.51 & 6 & 13.04 & 20 & 8.13 \\
\hline $31 \%$ and Above & 137 & 89.54 & 42 & 89.36 & 36 & 78.26 & 215 & 87.4 \\
\hline Total & 153 & 100 & 47 & 100 & 46 & 100 & 246 & 100 \\
\hline
\end{tabular}

Source: Data Analysis 2018

But in some places like Khartoum State farmers are using open places, under trees, or huts as their storage facilities with Storage loss estimated to be between 2\% to $80 \%$ with an average of $29 \%$ (Abdallah, and Ahmed 2015).

However the objectives of onion storage are to extend the period of availability of crop, maintain optimum bulb quality and minimize losses from physical, physiological, and pathological agents (Food and Agricultural Organization of the United Nation, 2013). But, the use of the traditional and unscientific method of storing Onion in the area makes the Onion to suffer greatly from weight loss and loss in economic/financial value (figure 3 ) as a result of inadequate ventilation spaces and absorption of heat by the roofing zinc during the day. This is because according to Srivastava, (1993) opined that temperature and humidity affect sprouting and rooting and many other Onion quality parameters as Between Onion $10-12 \mathrm{CO}$ sprouting to $25 \mathrm{Cis}{ }^{\circ}$ increase affected sprouting. by temperature. Rooting Temperatures is influenced by relative humidity $(\mathrm{RH})$. High $\mathrm{RH}$ promotes rooting, and weight loss is more when the temperature is above $35 \mathrm{C}$. The most suitable temperature for onion storage under ambient conditions is $25-35^{\circ} \mathrm{C}\left(30-35 \mathrm{C}^{\circ}\right)$ with a $\mathrm{RH}$ of $60-75 \%(65-70 \%)$. In cold storage, $0-2 \mathrm{C} 0$ temperature and $60-75 \% \mathrm{RH}$ is suitable. Under ambient conditions $\mathrm{RH}$ should not be less than $50 \%$ to avoid skin loss, and the preferable range is $60-75 \%$. An air flow rate of $165 \mathrm{M} 3 / \mathrm{h} / \mathrm{MT}$ is optimum for storage. Srivastava, (1993). 


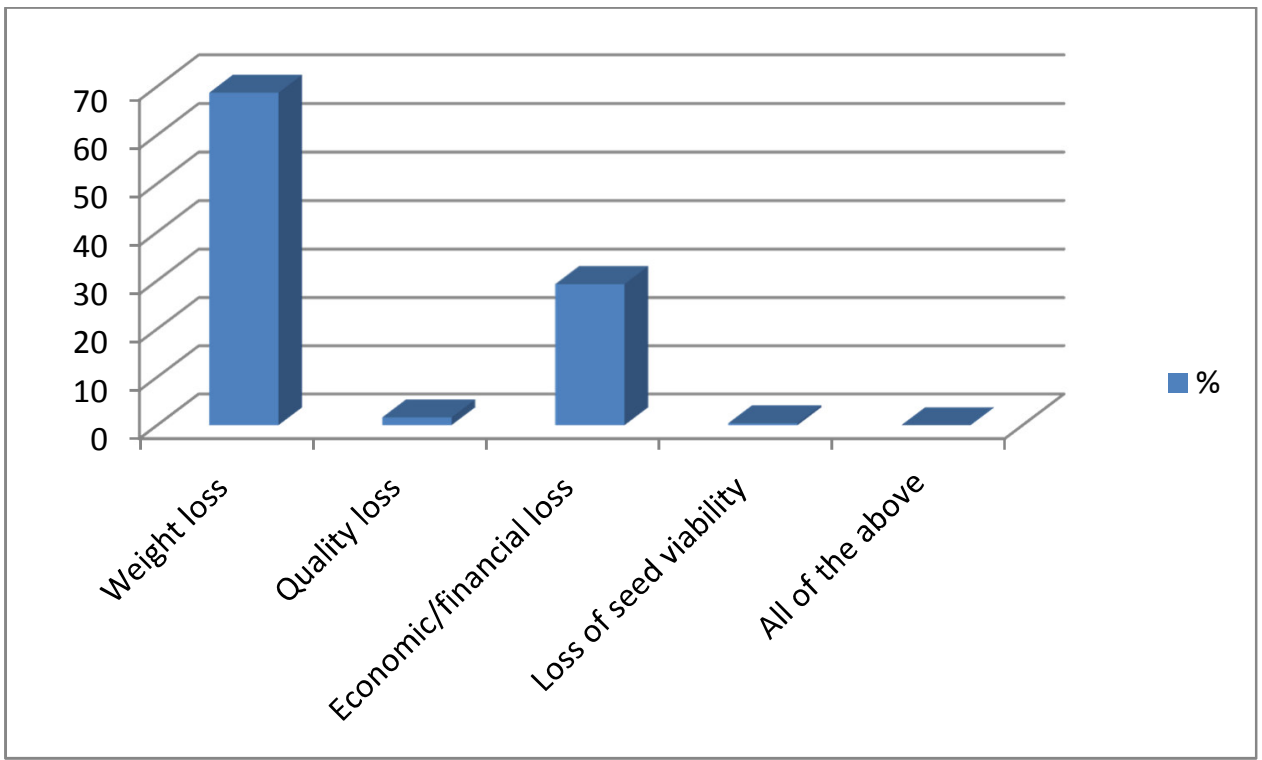

Figure 3: Types of Onion Loss

A data presented in table 2 shows that losses are higher in indigenous method of Onion storage $84.67 \%$ than in the Modern Onion Structure Three- tier Model 30.11\%. Above pre-test agree with Srivastava (1993) comparison study.

\section{0: Conclusion and Recommendation \\ 4.1 Conclusion}

Data obtained on the causes of Post harvest loss in the area indicated that, all the onion farmers' experiences post harvest loss. This post harvest loss is caused by Animals (rodents, rat and insect) (23.98\%), Inadequate storage facilities $(75.20 \%)$ and insignificant contribution of inappropriate transportation facilities $(0.81 \%)$. Inadequate storage facilities were recorded to be the highest causes of post harvest loss in the area. This incidence makes the farmers to incur loss in economic terms. Some of the respondents revealed that, out of hundred (100) bags of onion stored after harvesting is hardly to get thirty (30) bags in a year. This necessitates some farmers to sell their products immediately after harvesting at farm point or to market directly. The high rate of post harvest loss in the study area necessitate the farmers to adopt various methods of storing the onion such as local store (Rumbu), top of the roofing, use of basket, hanging method, spreading on the floor and spreading under tree in order to avoid post harvest losses and each method use depends on the ability and capability of the individual farmer. However, majority of the respondents (39.02) in the area use top of their roofing as a means of storing their products (Onion) and the use of basket (28.46). The rate of Onion loss incurs at storage duration post harvest as indicated by farmers/cultivars is between $31 \%$ and above of the total Onion produce by farmers $(87.4 \%)$ in all the sampled areas of the study area with the exception of very few farmers (4.47\%) that experiences about $11-20 \%$ loss of the Onion as a results of unscientific method of storage facilities like top of the roofing and baskets. But, the use of the traditional and unscientific method of storing Onion in the area makes the Onion to suffer greatly from weight loss and loss in economic/financial value as a result of inadequate ventilation spaces and absorption of heat by the roofing zinc during the day.

\subsection{Recommendations}

Following the findings of the study, it was recommended that,

1. There is need for the government and private Organization to provide assistance to the cultivars in order to build modern Onion Storage facilities so as to avoid post harvest loss.

2. Considering the nutritional value of Onion, there is need for the government and private Organizations/Individuals to provide Onion Processing plant that can be used for different purposes apart from food.

\section{Acknowledgement}

Salisu, Aliyu and Zahra'u are immensely grateful to Tertiary Education Trust Fund (TETFund), Nigeria for a research funding to Federal College of Education Kano-Nigeria through Institutional Based Research (IBR) this research work is fully funded by TETFund and we also like acknowledged the village head of Gundutse Alhaji Ibrahim Ahmad Gundutse (Dan Darman) Gundutse Town Kura Local Government Area in Kano State for his full cooperation and support on this work. 


\section{References}

Abdalla, I. and Ahmed, M. M., (2015). Study of Value chains of Onion production anad marketing in Khartoum State. Natural Resources, Agricultural Development and Food Security: International Research Network. International Working Paper Series, Paper Number 15/11. Retrieved on $4^{\text {th }}$ August, 2018 http://economia.unipv.it/naf/

Abduljabar A. (2004). Economics of Onion Retail Marketing in MMC Borno State Nigeria. Unpublished B. Agric Project Department of Agricultural Economics and Extension University of Maiduguri Borno State, Nigeria.

Agricultural Extension Research and Liaison Services Report (1985)

Chope, G. A. 2006. Understanding the mechanism behind onion bulb dormancy in relation to potential for improved onion storage. PhD Thesis submitted to Carnfield University. http://dspace.lib.cranfield.ac.uk/.../1826/.../Gemma_Chope_Thesis_2006.p...(accessed August 4, 2017)

Food and Agricultural Organization of the United Nation, (2013). ONIONNS: Post-Harvest Operation. Palmerston North, New Zealand: AGST/FAOI

Food and Agricultural Organization of the United Nation (2010): www.Faostat.vegetable.onion/Data. Retrieved 28/07/2017

Food and Agricultural Organization of the United Nation, (2012). World onion production. Food and Agriculture Organization of the United Nations. http:// faostat.fao.org, accessed December, 31, 2017.

Krejcie, R. V and Morgan, D. W (1970). Determining Sample Size of Research Activities. Educational and Psychological Measurement.

Kukanoor, L. 2005. Post harvest studies in onion. PhD Thesis submitted to the University of Agricultural Sciences, Dharwad. http://etd.uasd.edu/ft/th8441.pdf (accessed August 18, 2017)

María Eduvigis Roldán Marín (2009). Biological Activity and Nutritional Properties of Processed Onion Products. PhD Thesis submitted to the Department of Plant Food Science and Technology. Instituto del Frio Spanish National Research Council (CSIC). Madrid. SPAIN

Mrema, C.G. and S.R. Rolle, 2002. Status of the postharvest sector and its contribution to agricultural development and economic growth. Proceeding of the 9th JIRCAS International Symposium, (JIRCAS'08), Value-Addition to Agricultural Products, Ibaraki, Japan, pp: 13-20.

National population commission (2006) National population census official gazette

Olofin, E.A. (2008). The Physical Setting. In E. A. Olofin, Nabegu and Dambazau (Eds) Wudil within Kano Region. A Geographical Synthesis (pp 5-34). Kano: Adamu Joji.

Srivastava, K.J. (1993). Development of Improved Techniques for Big Onion Storage in Mahaweli System B (Sri Lanka). Mard Project Pimburattawa Report No. 220. Foundation, Nasik INDIA 